Effect of Plastic Mulch Color on Growth and Productivity of Different Summer Squash Varieties Grown Off-Season

\title{
S.Y. Attallah
}

Department of Vegetable Crops, Fac. of Agriculture, Assiut University Assiut, Egypt

Received on: $21 / 6 / 2016$

Accepted for publication on: 17/7/2016

\section{Abstract}

The current study describes the effect of coloured plastic mulch, clear and black polyethylene (PE), on growth and productivity of different summer squash varieties grown on February "off-season". A field experiment was carried out during 2012 and 2013 seasons at the Experimental Farm of Faculty of Agriculture, Assiut University, Assiut, Egypt. The performance of different parameters studied for plant received different mulch treatments was superior to the control (bare soil) treatment. The genotypic differences among squash varieties investigated were found significant for all the studied parameters. Clear PE mulch was significantly more effective than the black PE mulch in this respect. Plants of cvs sown on clear PE flowered earlier than those sown on black PE or bare soil.Total fruit yield (ton/fed) was significantly increased by using clear PE (total fruit yield was 12.61 and 12.94 ton/fed in the $1^{\text {st }}$ and $2^{\text {nd }}$ seasons, respectively; corresponding values for the bare soil were 7.61 and 7.74 ton/fed). Plants of 'Eskandrany' produced using clear PE were significantly the earliest to flower and gave the highest early and total fruit yield. It is concluded that mulching, especially clear PE, can be usefully utilized to enhance the summer squash production when grown off-season.

Keywords: cucurbita pepo, off-season, plastic mulch, production technology. 


\section{Introduction}

Summer squash is amongst the most important vegetable crops in Egypt as well as tropical and subtropical regions of the world. It can be produced the year round but grows better in warm weather. Under Egyptian growing conditions especially, early (off-season; late winter or early summer) production of such crop is faced with environmental limitations (prevailing low temperature). Mulching as one of the soil management techniques has been suggested by several authors to improve crop growth and productivity through enhancing soil warming and consequent water and nutrient uptake. The response of vegetable crops to mulch materials in terms of early maturity, better fruit quality and higher yield of tomato has been reported (Hussein et al., 2006; Bhella, 1988; West and Pierce, 1988). Black plastic mulch as a soil cover increased okra and squash vegetative growth and yield under rain-fed conditionsas compared with bare soil. (Mahadeen, 2014). In addition, plastic mulch increased soil temperature, e.g. in eggplant (Farghali, 1994), okra (Incalcatera et al., 2000), in pepper and okra (Abdel-Rahman, 2007).Black polyethylene (BPE) or clear polyethylene (CPE) mulch is preferred for winter production, because of their ability to transmit more solar energy and the ability of black PE to absorb more heat (Al-Masoum et al. 1998). Also, polyethylene (PE) film used in mulching play a great role in modifying soil moisture (VanDerWarken and WilcoxLee, 1988). Thus, the objective of this study was to investigate the effect of clear and black PE mulches on growth and productivity of summer squash cvs grown on February "off-season".

\section{Materials and Methods}

This study was carried out at the Experimental Farm of Faculty of Agriculture, Assiut University, Assiut, Egypt, during 2012 and 2013 seasons.

Plant material: Four summer squash (Cucurbita pepo L.) varieties viz. Eskandrany (1 and 2) produced by Misr for agricultureal development Co., Hybrid cv 'Amjad F1' and Hybrid cv 'New Eskandrany F1' produced by Misr hytech seed international Co., were investigated for their productivity under plastic mulch.

Mulch type: Black polyethylene (BPE) and clear transparent polyethylene (CPE) plastic films each 
of $50 \mu \mathrm{m}$ thickness were used as soil while mulch treatments were mulch applied prior to planting. randomly distributed to the sub-plots. Average temperature recorded, ${ }^{\circ} \mathrm{C}$ at After 10 days from irrigated the field, $10 \mathrm{~cm}$ depth in soil covered with plots were completely and tightly black or clear polyethylene (PE) covered with the plastic film, bare mulch or bare soil for the 4 summer soil plots were included as control. squash cultivars grown on February Seeds were soaked in warm water at during 2012 and 2013 seasons are $40{ }^{\circ} \mathrm{C}$ for $12 \mathrm{~h}$ and then incubated at presented in Table (1).

$30{ }^{\circ} \mathrm{C}$ in an electric incubator for 12

Expermental design: hours till the radical emergence. Experiment was laid out as split-plot Germinated seeds were planted in the in randomized complete-block design permanent field on 1 and 5 Feb., in with three replicates. The summer 2012 and 2013 season, respectively. squash cvs were in the main plots, 
Table 1. Average temperature $(\mathrm{C})$ recorded at $10 \mathrm{~cm}$ depth in soil under black and clear polyethylene (PE) mulch or bare soil for 4 summer squash cultivars grown on February during 2012 and 2013 seasons.

\begin{tabular}{|c|c|c|c|c|c|c|c|c|c|c|c|c|}
\hline \multirow{3}{*}{ Cultivars ${ }^{(a)}$} & \multicolumn{12}{|c|}{ Plastic Mulch ColorTreatments } \\
\hline & \multicolumn{4}{|c|}{ Bare soil (control) } & \multicolumn{4}{|c|}{ Black } & \multicolumn{4}{|c|}{ Clear } \\
\hline & E1 & E2 & A & $\mathrm{NE}$ & E1 & E2 & A & $\mathrm{NE}$ & E1 & $\mathrm{E} 2$ & $\mathrm{~A}$ & $\mathrm{NE}$ \\
\hline \multicolumn{13}{|c|}{$\underline{2012}$} \\
\hline February & 15.9 & 16.8 & 17.0 & 15.6 & 20.0 & 20.8 & 21.0 & 19.6 & 24.7 & 25.4 & 25.6 & 24.2 \\
\hline March & 18.5 & 19.3 & 19.5 & 18.2 & 22.2 & 23.1 & 23.3 & 21.8 & 26.6 & 27.3 & 27.5 & 26.1 \\
\hline April & 21.4 & 22.4 & 22.6 & 21.0 & 25.7 & 26.8 & 27.0 & 25.2 & 28.6 & 29.3 & 29.6 & 28.0 \\
\hline May & 24.8 & 26.1 & 26.3 & 24.3 & 28.2 & 29.3 & 29.6 & 27.7 & 31.2 & 32.1 & 32.4 & 30.6 \\
\hline \multicolumn{13}{|c|}{2013} \\
\hline February & 15.4 & 16.0 & 16.1 & 15.1 & 22.2 & 23.0 & 23.2 & 21.8 & 26.3 & 27.6 & 27.9 & 25.8 \\
\hline March & 17.2 & 18.0 & 18.2 & 16.9 & 23.9 & 24.8 & 25.0 & 23.4 & 27.7 & 28.8 & 29.1 & 27.2 \\
\hline April & 21.3 & 22.3 & 22.5 & 20.9 & 26.7 & 27.6 & 27.9 & 26.2 & 29.3 & 30.6 & 30.9 & 28.7 \\
\hline May & 24.0 & 24.9 & 25.1 & 23.5 & 27.9 & 28.7 & 29.0 & 27.4 & 30.2 & 31.8 & 32.1 & 29.6 \\
\hline
\end{tabular}

(a) Cultivars are: E1= Eskandrany 1, E2= Eskandrany 2, A= 'Amjad F1' Hybrid cv and $\mathrm{NE}=$ 'New Eskandrany F1' Hybrid cv. 
Planting was done $40 \mathrm{~cm}$ apart on the nouthern side of the ridge. Three ridges (70 $\mathrm{cm}$ apart and $3 \mathrm{~m}$ long) were included in each plot. The plants were fertilized with $300 \mathrm{~kg} /$ fed ammonium nitrate $(33.5 \% \mathrm{~N}), 200 \mathrm{~kg} / \mathrm{fed}$ calcium superphosphate $\left(\begin{array}{lll}15.5 \% & \mathrm{P}_{2} \mathrm{O}_{5}\end{array}\right)$ and 200 $\mathrm{kg} /$ fed potassium sulfate $\left(\begin{array}{lll}48 \% & \mathrm{~K}_{2} \mathrm{O}\end{array}\right)$. Half of these fertilizers amount was added during soil preparation. Other agricultural practices of irrigation, pest control..., etc, were applied as recommended for summer squash production (Hassan, 1991).

Data collection and analysis: Data were recorded on the following traits: 1) average fruits weight (g) per plant, total fruits yield (ton/feddan), fruit dry matter (\%), femininity tendency (\%) (female/male and female flower $\times 100$ ) and days to the anthesis of first female flower. Data were subjected to analysis of variance according to Snedecor and Cochran (1980). Means of the treatments were compared using the Least Significant Difference (LSD) test or Duncan's Multiple Range Test (DMRT) where appropriate at 0.05 propability level.

\section{Results}

\section{Effect of plastic mulch}

The tested mulch treatments showed an obvious effect on elevation of the soil temperature during cool weather as compared to the control (bare soil) and hence rapid warming of the soil (Table1). In 2012 season for all periods of growing season, the average bare soil temperature at $10 \mathrm{~cm}$ depth in the Eskandrany 1 plots ranged from $17^{\circ} \mathrm{C}$ to $26.3^{\circ} \mathrm{C}$ while from $25.6^{\circ} \mathrm{C}$ to $32.4^{\circ} \mathrm{C}$ as a result of using the clear polyethylene (PE) mulch $\left(6.1^{\circ} \mathrm{C}-8.6^{\circ} \mathrm{C}\right.$ higher than those of control). The black $\mathrm{PE}$ showed $3^{\circ} \mathrm{C}-4^{\circ} \mathrm{C}$ higher than those of control.

Mulch treatments showed a significant effect on average fruit weight per plant, total fruits yield and percentage of fruit dry matter (Table 2). Mulching produced higher fruits weight per plant than control. The highest yield of fruits per plant was recorded for clear $\mathrm{PE}$ mulch (728.7 and $747.9 \mathrm{~g}$, respectively) followed by black plastic mulch in both seasons. The control showed the lowest fruit weight per plant (462.8 and $470.4 \mathrm{~g}$ in first and second seasons, respectively). Observation on the femininity tendency followed a closely similar trend to average fruits weight per plant and total fruits yield (Table 3). Control treatment produced lowest fruits yield in both seasons (7.611 and 7.737 tons, respectively). Clear $\mathrm{PE}$ mulch performance better than black PE mulch 
and showed highest total fruits yield per feddan, which recorded 12.606 and 12.938 tons in first and second season, respectively. Also, it is obvious that fruit dry matter was increased under mulching than control. Moreover, higher fruit dry weight percentage $(7.0 \%$, in both seasons) recorded with clear PE mulch compared to black PE mulch (5.8 and 5.9 $\%$, in both seasons) and control (4.9 and $5.0 \%)$.

The analysis of variance for number of days lapsed to first female flower appearance of four squash cvs grown under plastic mulch exhibited significant effects (Table 3). Due to using mulch, days to first female flower decreased compared to control in both season. Less number of days to first female flower was recorded with clear plastic mulch in both seasons (29.6 and 29.4 days, respectively). It seemed that clear PE was performance better than black PE.

\section{Varieties performance and their} interaction with soil mulch treatments

Results in Table (2 and 3) indicate that cultivar Amjad F1 scored highest average fruits yield per plant, total fruits yield and femininity tendency in both season while cv Eskandrany 1 gave the highest value for average dry matter percentage in fruits and number of days to first female flower anthesis.

Eskandrany-1 under clear PE mulch exhibited the highest fruits yield per plant (760.4 and 782.3 $\mathrm{g}$ in both seasons, respectively) compared to control (254.2 and 259.9 $\mathrm{g}$ in both seasons, respectively). Also, variety Eskandrany-1 gave the highest total yield of fruits in both seasons, which recorded 13.154 and 13.533 tons per feddan compared to control (4.321 and 4.417 tons). Maximum percentage of fruits dry metter was recorded in variety Eskandrany-1, which was 8.5 and $8.1 \%$ in first and second seasons, respectively. The control gave 5.1 and $5.3 \%$ of fruit dry weight in both seasons, respectively.

Results in Table (3) indicate that the highest value of femininity tendency was recorded in variety Amjad F1 in the two seasons (30.8 and 31.1) under clear PE compared to control (21.8 and 22.3, in both seasons). Also, variety of $\mathrm{New}$ Eskandrany F1 scored less number of dats to first female flower in frist and second season (27.7 days in both seasons) as compared to control (36.2 and 35 days, respectively).

\section{Discussion}

In the present work, records of temperature for the tested mulch treatments showed an obvious effect in elevation of the soil temperature as 
compared to the control (bare soil). Use of clear plastic was superior to the black one in this regard. The present findings are in harmony with previous reports of Mashingaidze et al.(1996) who indicated that mean weekly soil temperature was the higest under clear plastic mulch and generally lowest under the black plastic covers. Furthermore, Wolfe et al. (1989) found that clear mulch increased soil temperatures more than black mulch. Also, Frank and Heineman (1987) found that the warmest temperatures were noted under the clear plastic cover and the coolest under the black plastic cover. Gabriel et al. (1994) indicated that clear PE mulch showed the highest soil temperature and white/black film the lowest.

Earlier plant growth and earlier crop production are two of the primary benefits of using black and clear plastic mulches (Lamont, 1993). Earlier crop production generally results in higher market prices and higher yields. Color affects the surface temperature of the mulch and the underlying soil temperature. Ham et al. (1993) indicated that if the clear plastic had been placed loosely on the surface, so that an insulating air gap would have been established then greater heat storage or less heat loss might have occurred. Black mulch absorbs most ultra-violet (UV), visible, and infrared wavelengths (IR) of incoming solar radiation and re-radiates absorbed energy in the form of thermal radiation or long-wavelength infrared radiation. Much of the solar energy absorbed by black plastic mulch is lost to the atmosphere through radiation and forced convection. In contrast, clear plastic mulch absorbs little solar radiation but transmits $85 \%$ to $95 \%$, with relative transmission depending on the thickness and degree of opacity of the polyethylene. The under surface of clear plastic mulch usually is covered with condensed water droplets. This water is transparent to incoming shortwave radiation but is opaque to outgoing longwave infrared radiation; so much of the heat lost to the atmosphere from a bare soil by infrared radiation is retained by clear plastic mulch. Thus, daytime soil temperatures under clear plastic mulch are generally 8 to $14^{\circ} \mathrm{F}$ higher at a 2 -inch depth and 6 to $9^{\circ} \mathrm{F}$ higher at a 4-inch depth compared to those of bare soil.

Generally, Ashworth and Harrison (1983) showed that plastic mulches are used to modify environmental condition and improve crop yield throughout the increase of soil temperature. Our observations suggested that differences 
between the two tested mulch treatments regarding soil temperatures were more obvious early in the growing season, while became close to each other as plants progressed in age. It is noticeable that records of temperature in plots of $\mathrm{cv}$ Amjad F1 were, generally, higher than their respective values recorded in plots of other cvs. The most obvious differences in temperatures (ranging from $1.3^{\circ} \mathrm{C}-1.4^{\circ} \mathrm{C}$ ) were obtained during earlier stages of growth. Results of present work revealed that cv Amjad F1 exhibited enhanced flowering and promoted earlier crop yield.

Table 2. Average fruits yield/plant (g), total fruits yield (ton/fed) and average fruit dry matter (\%) for 4 summer squash cultivars grown on February during 2012 and 2013 seasons ${ }^{*}$ as affected by soil mulch under Assiut conditions ${ }^{(1)}$.

\begin{tabular}{|c|c|c|c|c|c|c|c|c|}
\hline $\begin{array}{l}\text { Soil mulch (B) } \\
\text { Cultivar } \\
\text { (A) }\end{array}$ & 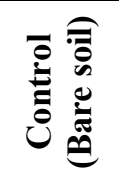 & $\begin{array}{l}\frac{5}{2} \\
\frac{y}{0} \\
\frac{\pi}{0}\end{array}$ & $\frac{\sqrt[c]{1}}{0}$ & 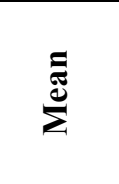 & 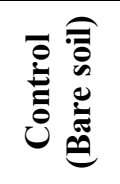 & $\begin{array}{l}\frac{1}{a} \\
\frac{y}{0} \\
\frac{\pi}{n}\end{array}$ & 淧 & $\sum_{\Sigma}^{\text {J્ }}$ \\
\hline & \multicolumn{8}{|c|}{ A- Average fruit yield/plant (g) ${ }^{(2)}$} \\
\hline & \multicolumn{4}{|c|}{2012} & \multicolumn{4}{|c|}{$\underline{2013}$} \\
\hline Eskandrany1 & $254.2 d$ & $553.7 \mathrm{~d}$ & $760.4 a$ & 522.7 & $259.9 d$ & $566.1 d$ & $782.3 \mathrm{a}$ & 536.1 \\
\hline Eskandrany2 & $536.7 \mathrm{~b}$ & $627.0 \mathrm{~b}$ & $719.8 b$ & 627.8 & $537.2 b$ & $641.1 \mathrm{~b}$ & $736.0 \mathrm{~b}$ & 638.1 \\
\hline Amjad F1 & $551.0 \mathrm{a}$ & $664.2 \mathrm{a}$ & $756.5 \mathrm{a}$ & 657.2 & $563.5 \mathrm{a}$ & $679.2 \mathrm{a}$ & $779.7 \mathrm{a}$ & 674.1 \\
\hline New Eskandrany F1 & $509.4 \mathrm{c}$ & $590.8 \mathrm{c}$ & $678.2 \mathrm{c}$ & 592.8 & $520.9 \mathrm{c}$ & $604.2 \mathrm{c}$ & $693.4 \mathrm{c}$ & 606.2 \\
\hline Mean & 462.8 & 608.9 & 728.7 & 600.1 & 470.4 & 622.6 & 747.9 & 613.6 \\
\hline \multirow{3}{*}{$\mathrm{LSD}_{0.05}{ }^{(3)}$} & \multicolumn{4}{|c|}{11.9} & \multicolumn{4}{|c|}{17.2} \\
\hline & \multicolumn{8}{|c|}{ B- Total fruit yield (ton/ feddan) ${ }^{(2)}$} \\
\hline & \multicolumn{4}{|c|}{$\underline{2012}$} & \multicolumn{4}{|c|}{$\underline{2013}$} \\
\hline Eskandrany1 & $4.321 \mathrm{c}$ & $9.578 \mathrm{~d}$ & $13.154 \mathrm{a}$ & 9.017 & $4.417 \mathrm{c}$ & $9.794 d$ & $13.533 \mathrm{a}$ & 9.248 \\
\hline Eskandrany2 & $8.587 b$ & $10.847 b$ & $12.452 \mathrm{c}$ & 10.628 & $8.594 b$ & $11.090 \mathrm{~b}$ & $12.733 b$ & 10.806 \\
\hline Amjad F1 & $8.981 \mathrm{a}$ & $11.490 \mathrm{a}$ & $13.087 \mathrm{~b}$ & 11.186 & $9.184 \mathrm{a}$ & $11.749 \mathrm{a}$ & $13.489 \mathrm{a}$ & 11.474 \\
\hline New Eskandrany F1 & $8.557 \mathrm{~b}$ & $10.221 \mathrm{c}$ & $11.731 \mathrm{~d}$ & 10.170 & $8.751 \mathrm{~b}$ & $10.452 \mathrm{c}$ & $11.996 \mathrm{c}$ & 10.400 \\
\hline Mean & 7.611 & 10.534 & 12.606 & 10.250 & 7.737 & 10.771 & 12.938 & 10.482 \\
\hline \multirow[t]{3}{*}{$\mathrm{LSD}_{0.05}{ }^{(3)}$} & \multicolumn{4}{|c|}{0.215} & \multicolumn{4}{|c|}{0.302} \\
\hline & \multicolumn{8}{|c|}{ C- Average fruit dry matter $(\%)^{(2)}$} \\
\hline & \multicolumn{4}{|c|}{$\underline{2012}$} & \multicolumn{4}{|c|}{2013} \\
\hline Eskandranyl & $5.1 \mathrm{a}$ & $6.3 \mathrm{a}$ & $8.5 \mathrm{a}$ & 6.6 & $5.3 \mathrm{a}$ & $6.5 \mathrm{a}$ & $8.1 \mathrm{a}$ & 6.6 \\
\hline Eskandrany2 & $4.9 \mathrm{~b}$ & $5.6 \mathrm{c}$ & $6.5 \mathrm{c}$ & 5.7 & $4.9 \mathrm{~b}$ & $5.8 \mathrm{c}$ & $6.8 \mathrm{c}$ & 5.8 \\
\hline Amjad F1 & $4.9 \mathrm{~b}$ & $5.9 \mathrm{~b}$ & $6.9 \mathrm{~b}$ & 5.9 & $5.2 \mathrm{a}$ & $6.0 \mathrm{~b}$ & $7.0 \mathrm{~b}$ & 6.1 \\
\hline New Eskandrany F1 & $4.6 c$ & $5.3 \mathrm{~d}$ & $6.2 \mathrm{~d}$ & 5.3 & $4.7 \mathrm{c}$ & $5.5 \mathrm{~d}$ & $6.3 \mathrm{~d}$ & 5.5 \\
\hline Mean & 4.9 & 5.8 & 7.0 & 5.9 & 5.0 & 5.9 & 7.0 & 6.0 \\
\hline $\mathrm{LSD}_{0.05}{ }^{(3)}$ & \multicolumn{4}{|c|}{0.1} & \multicolumn{4}{|c|}{0.1} \\
\hline
\end{tabular}

\footnotetext{
(1) variance of soil mulch treatments $\mathrm{x}$ cultivars $\mathrm{x}$ year interaction was significant.

(2) means within column followed by same letter(s) are not significantly different at 0.05 level of probability using the Duncan Multiple range Test (DMRT).

(3) to compare soil mulch treatments for the same cultivar.
} 
Table 3. Femininity tendency and number of days to first female flower anthesis for for 4 summer squash cultivars grown on February during 2012 and 2013 seasons as affected by soil mulch under Assiut conditions ${ }^{(1)}$

\begin{tabular}{|c|c|c|c|c|c|c|c|c|}
\hline Sqil mulche (B) & 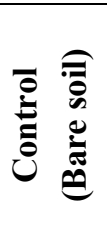 & 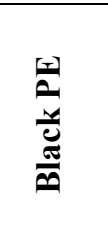 & 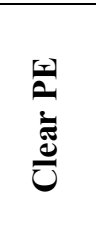 & 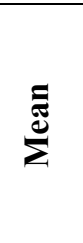 & 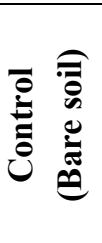 & 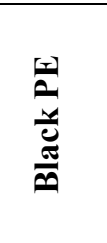 & $\frac{\sqrt{0}}{\overline{0}}$ & $\stackrel{\Xi}{\stackrel{\Xi}{J}}$ \\
\hline & \multicolumn{8}{|c|}{$\underline{\text { A- Femininty tendency(female/male and female flower }) \times 100^{(2)}}$} \\
\hline & \multicolumn{4}{|c|}{2012} & \multicolumn{4}{|c|}{$\underline{2013}$} \\
\hline Eskandrany1 & $10.3 \mathrm{~d}$ & $21.9 \mathrm{~d}$ & $30.4 \mathrm{a}$ & 20.9 & $10.6 \mathrm{~d}$ & $22.2 \mathrm{~d}$ & $25.7 \mathrm{~d}$ & 19.5 \\
\hline Eskandrany2 & $21.2 \mathrm{~b}$ & $25.6 \mathrm{~b}$ & $28.5 b$ & 25.1 & $21.8 \mathrm{~b}$ & $25.2 \mathrm{~b}$ & $29.5 b$ & 25.5 \\
\hline Amjad F1 & $21.8 \mathrm{a}$ & $26.1 \mathrm{a}$ & $30.8 \mathrm{a}$ & 26.2 & $22.3 \mathrm{a}$ & $27.2 \mathrm{a}$ & $31.1 \mathrm{a}$ & 26.8 \\
\hline New Eskandrany F1 & $20.6 \mathrm{c}$ & $23.4 \mathrm{c}$ & $27.7 \mathrm{c}$ & 23.9 & $20.6 c$ & $24.0 \mathrm{c}$ & $27.5 \mathrm{c}$ & 24.0 \\
\hline Mean & 18.5 & 24.2 & 29.3 & 24.0 & 18.8 & 24.6 & 28.4 & 23.9 \\
\hline \multirow[t]{3}{*}{$\mathrm{LSD}_{0.05}{ }^{(3)}$} & \multicolumn{4}{|c|}{0.5} & \multicolumn{4}{|c|}{0.3} \\
\hline & \multicolumn{8}{|c|}{$\underline{B}^{-}$Number of days to first female flower anthesis ${ }^{(2)}$} \\
\hline & \multicolumn{4}{|c|}{$\underline{2012}$} & \multicolumn{4}{|c|}{$\underline{2013}$} \\
\hline skandrany1 & $42.3 \mathrm{~d}$ & $33.7 \mathrm{c}$ & $31.0 \mathrm{c}$ & 35.7 & $43.2 \mathrm{~d}$ & $34.1 \mathrm{c}$ & $30.3 \mathrm{c}$ & 35.8 \\
\hline Eskandrany2 & $36.9 b$ & $33.1 \mathrm{~b}$ & $28.8 b$ & 32.9 & $37.4 \mathrm{~b}$ & $32.9 b$ & $28.5 b$ & 32.9 \\
\hline Amjad F1 & $37.4 \mathrm{c}$ & $33.6 \mathrm{c}$ & $20.8 \mathrm{c}$ & 33.9 & $38.0 \mathrm{c}$ & $35.5 \mathrm{~d}$ & $31.2 \mathrm{~d}$ & 34.9 \\
\hline New Eskandrany F1 & $36.2 \mathrm{a}$ & $30.4 \mathrm{a}$ & $27.7 \mathrm{a}$ & 31.4 & $35.0 \mathrm{a}$ & $31.1 \mathrm{a}$ & $27.7 \mathrm{a}$ & 31.3 \\
\hline Mean & 38.2 & 32.7 & 29.6 & 33.5 & 38.4 & 33.4 & 29.4 & 33.7 \\
\hline $\operatorname{LSD}_{0.05}{ }^{(3)}$ & \multicolumn{4}{|c|}{0.3} & \multicolumn{4}{|c|}{0.2} \\
\hline
\end{tabular}

(1) variance of soil mulch treatments $\mathrm{x}$ cultivars $\mathrm{x}$ year interaction was significant.

(2) means within column followed by same letter(s) are not significantly different at 0.05 level of probability by using the Duncan Multiple Range Test (DMRT).

(3) to compare soil mulch treatments for the same cultivar.

\section{Literature Cited}

Abdel-Rahman, M.S.S.; M.A. Farghali, H.A. Hussein and M.M.A. Abdalla. 2007. Soil mulch effect on the enhancement on growth and early yield of okra and pepper under Assiut conditions., $1^{\text {st }}$ Conference of Young Scientists Faculty Agric., Assiut Univ., 17-18 April, 2007.

Al-Masoum, A.A.; A.A. Hashim; K. Jaafer and A. Al-Asaal. 1998. Effect of two mulch types for solarization on soil temperature. Agricultural Mechanization in Asia, Africa and Latin America. (C.F. CAB Abstr. 1998/08-2000/07).

Ashworth, S. and H. Harrison. 1983. Evaluation of mulches for use in the home garden. Hort. Sci. 18: 180-182.

Bhella, H.S. 1988. Tomato response to trickle irrigation and black polyethylene mulch. J. Amer. Soc. Hort. Sci. 113 (4): 543-546.

Farghali, M.A. 1994. Effect of plastic mulches on off season Eggplant production. Assiut J. Agric. Sci. 25 (3): 97-112.

Frank J. Dainello and R.R. Heineman. 1987. Influence of polyethylenecovered trenches on yield of Bell papper. Hort. Sci. 22 (2): 225-227.

Gabriel, E.L., H. Lotti, R.M. Genito and O.R. Larrogue. 1994. Effect of mulch color on yield of freshmarket tomatoes (Lycopersicon 
esculentum). Acta. Hort. 357, 243250.

Ham, J.M., G.J. Kluitenberg and W.J. Lamont. 1993. Optical properties of plastic mulches affect the field temperature regime. J. Amer. Soc. Hort. Sci. 118 (2): 188-193.

Hassan, A. A. 1991. Production of vegetable crops.1st ed., Published by Arab House for Publishing and Distribution, Cairo, Egypt. (in Arabic).

Incalcaterra, G. and F. Vetrano. 2000. Effects of two sowing dates and plastic mulch on okra production. Acta Hort 533:329-336

Lamont, W.J. 1993. Plastic mulch for the production of vegetable crops. HortTechnology 3:35-39.

Mahadeen, A.Y. 2014. Effect of polyethylene black plastic mulch on growth and yield of two summer vegetable crops under rainfed conditions under semi-arid region conditions. American J. Agric. Biol. Sci., 9(2): 202-207.

Mashingaidze, A.B.; O.A. Chivinge and C. Zishiri. 1996. The effects of clear and black plastic mulch on soil temperature, weed seed viability and seedling emergence, growth and yield of tomatoes. J. App. Sci. Southern Africa. 2 (1):
6-14. (C.F. CAB Abstr. 19961998/07).

Hussein H.A., M.A. Farghali, G.A.ELGharably and S.Y. Attallah. 2006. Growth and yield and its components in some tomato cultivars grown on different dates as affected by soil mulch under Assuit conditions. 2- yield and its components . The third scientific conference of Agricultural sciences, Nov., 6-9, Fac. Agric., Minia, Egypt.

Snedecor, C.W. and W.G. Cochran. 1980. Statistical methods. 6th ed. Iowa Univ. Press, Ames, Iowa, U.S.A.

VanDerweken, J. E. and D.Wilcox-Lee. 1998. Influence of plastic mulch and type and frequency of irrigation on growth and yield of bell pepper. HortScience 23:985-988.

West, J. and L.C. Pierce. 1988. Yield of tomato phenotypes modified by planting density, mulch and row covers. HortScience 23:321-324.

Wolfe, D.W., L.D. Albright and J. Wyland. 1989. Modeling row cover effects on microclimate and yield: I- Growth response of tomato and cucumber. J. Amer. Soc. Hort. Sci. 114 (4): 562-568. 
تأثير لون اغطية التربة البلاستيكية على النمو والانتاجية فى اصناف الكوسة المختلفة

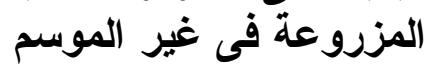

شرين يعقوب عطا لله

قسم الخضر - كلبة الزر اعة- جامعة اسيوط عطاب

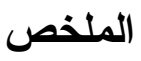

اجريت هذة الدر اسة بمزرعة التجارب البحثية - كلية الزر اعة - جامعة اسـيوط وذلــك

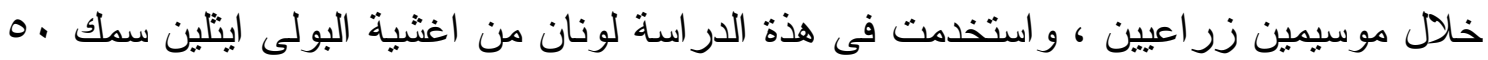

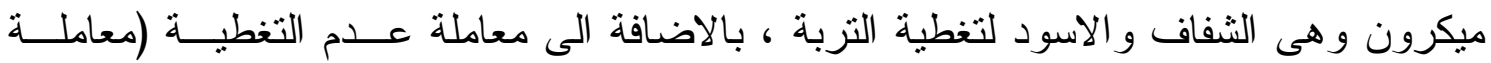
المقارنة) وكذللك استخدمت ؛ اصناف من الكوسة وهى اسكندر انى (،اسكندر انى ب، هجين امجد

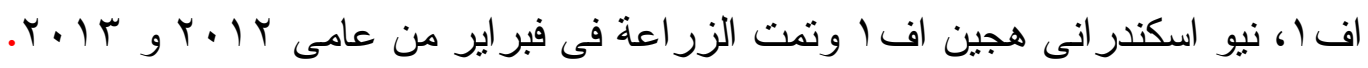

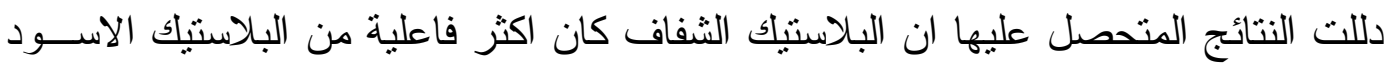
فى هذة الدراسة، حيث ادى استخدام البلاستيك الثفاف الى الازهار المبكــر للنباتــات مقارنـــة

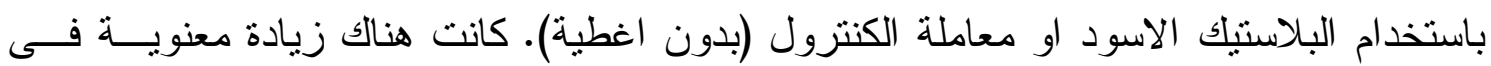

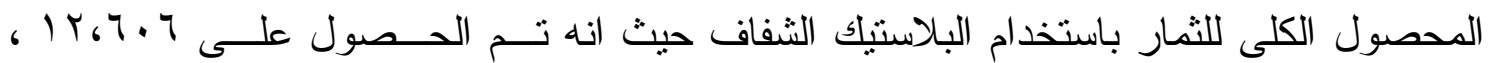

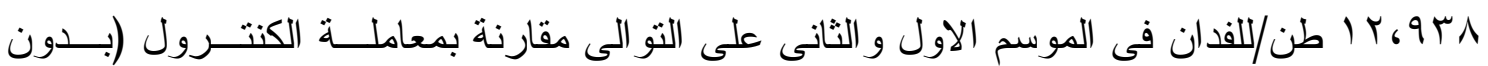

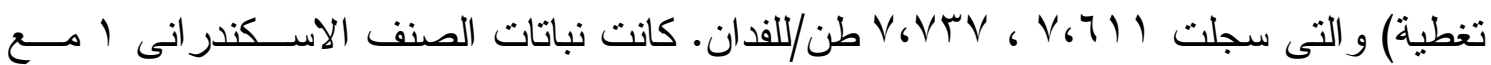
استخدام البلاستيك الثفاف هى المعاملة الاكثر تبكير ا فى الاز هار وكذلك الاعلى فى المحـصول الكلى ، ويتبين من هذة الدر اسة ان اغطية التربة وخاصة استخدام البلاسـتيك الــشفاف تعتبــر طريقة فعالة لزيادة انتاجية محصول الكوسة عند الزر اعة المبكرة. 